\title{
DAGMAR HORNA-PERMAN, 1925-1978
}

Students of Czechoslovak and twentieth-century European diplomatic history and bibliography were saddened to hear that Professor Dagmar Horna-Perman of Georgetown University died on May 26, 1978, while visiting Jerusalem.

Ms. Horna-Perman was born of Czech parents in Bratislava, the capital of Slovakia, on November 2, 1925. Her father, Richard Horna, was a student of legal history and a professor of law who had been sent by the Czechoslovak government to Bratislava to help organize the School of Law of the newly founded (1919) Comenius University. Her schooling in Bratislava was interrupted by the Munich Conference in 1938, which led to the breakup of Czechoslovakia and her family's return to Prague where she completed her secondary school education. After World War II she matriculated in the graduate school of business administration of the Prague Institute of Technology. Once again politics interfered with her plans, however. After the 1948 Communist coup in Prague, which put an end to the Third Czechoslovak Republic, she fled to Switzerland where she attended the Handelshochschule of the University of St. Gallen. She subsequently emigrated to the United States and continued her studies at the University of Kansas and the University of California, Berkeley. She received her A.M. degree at Kansas in 1949 and her Ph.D. in political science and history at California in 1954. Her doctoral dissertation, prepared under the direction of the late Professor Robert J. Kerner, dealt with the Czechoslovak question at the Paris Peace Conference. It was inspired by the work of her father, who had served as adviser to the Czechoslovak-Hungarian frontier delimitation commission and had published an early study of Czechoslovakia's frontier-making in 1924. His sources were limited, however, while the extensive documentation that Ms. Horna-Perman found in the National Archives in Washington and at the Hoover War Library in Stanford enabled her to produce the definitive study on the subject, entitled The Shaping of the Czechoslovak State: Diplomatic History of the Boundaries of Czechoslovakia, 1914-1920 (Leiden: E. J. Brill, 1962).

After receiving her doctorate, Ms. Horna-Perman worked as director of the American Historical Association's "Alexandria project" in 1957-59, microfilming and cataloging captured German documents. In 1966-67, she was a staff member of the AHA joint committee on bibliographical services to history, which led to the publication of Bibliography and the Historian (Santa Barbara: ABC-Clio Press, 1968), which she edited and coauthored. In 1972, she joined the Department of History at Georgetown University. In between and during these jobs she raised a family (she had two children). She had plans for further research and publication when cancer prematurely cut her life short at the age of fifty-two.

VICTOR S. MAMATEY

University of Georgia 